\title{
THE (MIS)COMPLIANCE OF OBJECTIVES OF NEW CAP - LEGISLATIVE, ACADEMIC AND GENERAL PUBLIC PERSPECTIVES
}

\author{
Eva Daniela CVIK ${ }^{1}$, Radka MacGREGOR PELIKÁNOVÁ
}

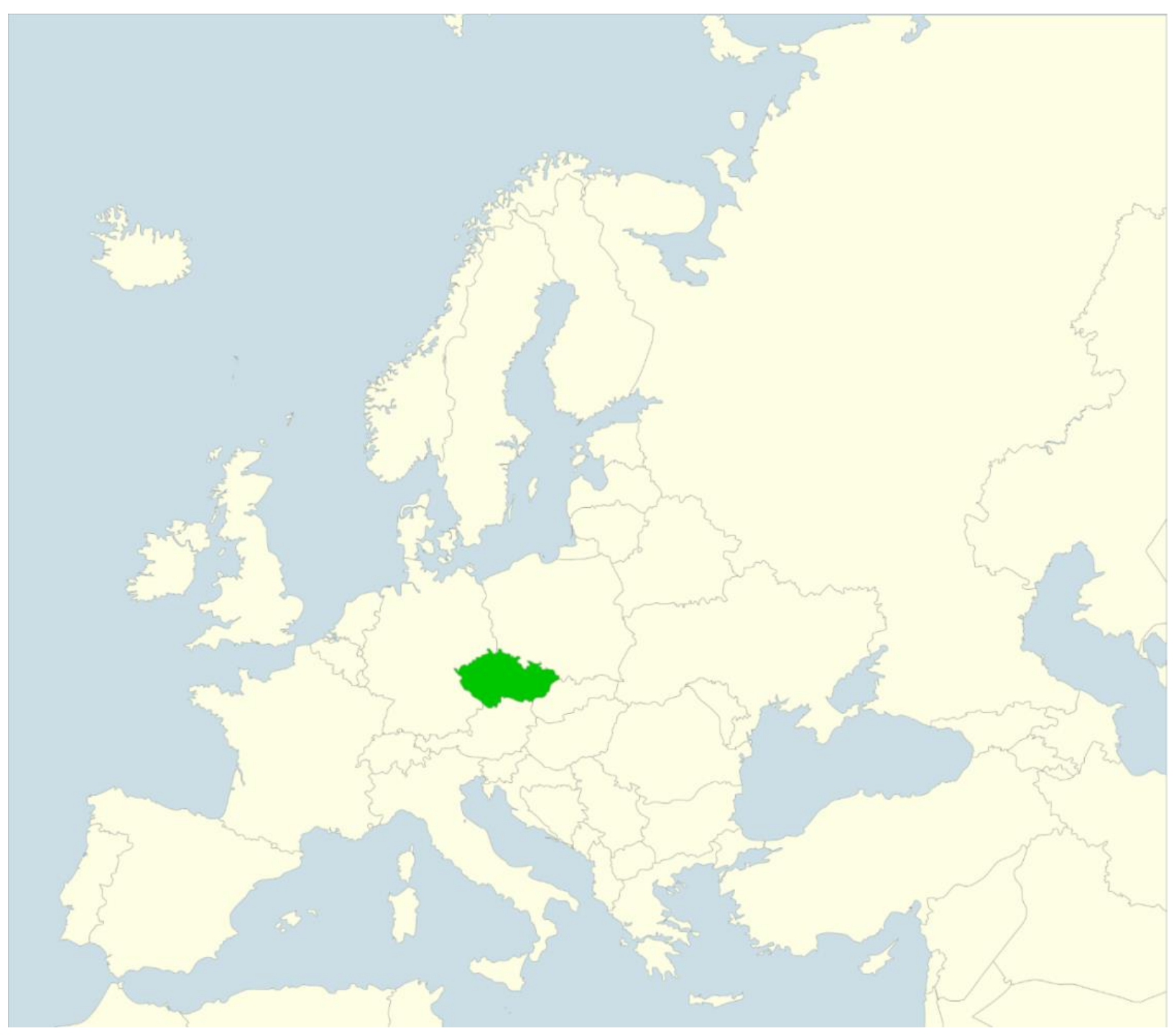

1 JUDr. Ing. Eva Daniela Cvik, Ph.D. et Ph.D., Department of Law, Faculty of Economics and Management, Czech University of Life Sciences Praha, Kamýcká 129, 16500 Praha 6, Czechia; email: cvik@pef.czu.cz

2 JUDr. Radka MacGregor Pelikánová, Ph.D., LLM, MBA, Metropolitan University Praha, Dubečská 19, 10031 Praha 10; Czechia; email: radkamacgregor@yahoo.com 


\begin{abstract}
For over 50 years, the Common Agricultural Policy (CAP) has been fundamental for European integration, while taking up to $40 \%$ of the budget. The new CAP uses various funds and aims at both agricultural production support and rural development. This dichotomy is confirmed by the Treaty on functioning of the EU and developed by various Regulations and Directives. However, are the stated and implied objectives of the primary and secondary EU law under the auspices of the strategy Europe 2020 in compliance? A pioneering holistic Meta-Analysis of the legislative setting, academic treatises and general public perceptions reveals an unexpected byzantine mosaic of expressed and implied objectives, which are hardly to be reconciled. This threat to the new CAP needs to be addressed. Smart, sustainable and inclusive growth demands a reconciliation of efforts and objectives and cannot afford their fragmentation and anti-polarity.
\end{abstract}

Key words: Common agricultural policy, objectives, compliance

\begin{abstract}
Abstrakt: (Ne)soulad cílů nové společně zemědělské politiky - pohledy legislativní, akademické a široké veřejnosti. Společná zemědělská politika (SZP) je již vice než 50 let klíčovou pro evropskou integraci, priičemž využívá až 40\% rozpočtu. Nová SZP je podpořena řadou fondů a usiluje o podporu zemědělské výroby i o rozvoj venkova. Tato dichotomie je potvrzena Smlouvou o fungování EU a rozvinuta řadou nařízení a směrnic. Avšak jsou v souladu stanovené i vyplývající cíle primárního a sekundárního práva EU pod záštitou strategie Evropa 2020? Novátorská holistická Meta-Analýza legislativního nastavení, akademických rozborů a názorů veřejnosti odhaluje neočekávanou spletitou mozaiku výslovných i implicitních cílů, které jsou těžko sladitelné. To je hrozba pro novou SZP, se kterou je třeba se vypořádat. Chytrý, udržitelný a inkluzivní růst vyžaduje sladění úsilí a cílů a nemůže se dovolit jejich roztříštěnost a protichůdnost.
\end{abstract}

Klíčová slova: Společná zemědělská politika, cíle, soulad

\title{
1. Introduction
}

Agriculture has a strong influence on the shaping of the EU (Blacksell, 2010) and the EU is well aware about that. Indeed, agriculture is a fundamental component of European economy and society (Nazzaro \& Marotta, 2016) and its significance is growing, along with the importance of using renewable resources and the subsidence of sustainable development (Martinát \& Turečková, 2016). Since the establishment of the famous three European communities, agriculture has been at the very heart of modern European integration. The Common Agricultural Policy ("CAP") was officially created in 1962 to regulate and support the European agricultural sector (Reiff et al., 2016). The CAP was significantly reformed in 1992 and 2003. The most recent reform has importantly reshaped the CAP, i.e., created the so- called new CAP, while focusing on producer support, a land-based approach and sustainable agriculture with "green" direct payments (Severini \& Sorrentino, 2017). Namely, for the period 2014-2020, the production and price regulations, along with compensation payments, were replaced by instruments linked to the $1^{\text {st }}$ and $2^{\text {nd }}$ pillars of the new CAP, i.e., by direct payments and the Rural Development Policy ("RDP"). Therefore, the original concerns regarding the management of scarce food supplies were replaced in the post-Lisbon EU for the new CAP by different objectives.

Although the EU law should follow the ten-year strategy for 2010-2020, Europe 2020, and the secondary EU law should be in compliance with the primary EU law, discrepancies exist. Europe 2020 mentions smart, sustainable and inclusive growth, while the primary EU law, represented by the Treaty on the EU ("TEU") and Treaty on the functioning of the EU ("TFEU"), indicates a stable, sustainably produced supply of safe food at affordable prices for Europeans, while also ensuring a decent standard of living for farmers and agricultural workers. In the context 
of sustainability, the focus on the social responsibility of states, businesses and the citizenry is growing (Pakšiová, 2016). However, the wording of the secondary EU law, represented by various Regulations and Directives, points to other objectives. The understanding of these objectives is critical because, under the principle of conferral, the EU shall act only within the limits of the competences conferred by EU member states to attain set objectives. R \& D Tax Incentives are one of the ways farmers can achieve the Europe 2020 goals (Bočková, 2014).

The teleological interpretation of these legislative texts in the light of provided finances adds further complexity and heterogeneity. The academic treatises built upon this tangled legislation offer a myriad of opinions and statements about what is (not) and/or should(not) be the objective of the new CAP. Naturally, the feelings of the ultimate stakeholders should not be overlooked, namely the expectation of the CAP addresses, e.g., Czech farmers.

Thus it is plain as day that, until 2020, billions of EUR go and will continue to go for direct payments and rural development to achieve new CAP objectives. However, what are these objectives? Are they in compliance? Can they be in compliance? What should be done to make them reconcilable? These are very burning questions indeed, because obviously, reconciled and harmonized objectives lead to the flowering new CAP and support the prospects of the EU, while mis-reconciled and contradicting objectives set up the new CAP towards failure and make the modern European integration even more challenging and questionable.

\section{Theoretical and financial background}

Modern European integration has always faced many objections regarding the selection of the models and approaches used (MacGregor Pelikánová, 2013). The European Union (EU) is a heterogeneous unit with significant disparities between its Member States and particularly among their regions in many areas of the modern economy, and the CAP embodies some of these disparities, divergences (Melecký and Staníčková, 2017). The CAP was conceived as, and remains, the common policy for the regulation of agricultural production and for providing financial support for the development of agriculture. Originally, a major concern was the threat of the insufficiency of the agricultural production and self-sufficiency, and thus the CAP should, along with technical advancement, lead to the primarily quantitative growth and in particular to an increase in productivity, living standards, and stability of production and markets. The original triad of principles included the creation of a single agricultural market, community preference and financial solidarity. This led to, both animadverted and applauded, measures, such as the central fixing of prices, freedom of movement of agricultural products between EU member states, imposing an import tax and duties (so as to protect European farmers and their agricultural production) and providing export subsidies (to make European agricultural production competitive in international markets). Naturally, these measures were prone to misleading perceptions, as is the norm in such a setting (MacGregor Pelikánová et al., 2017 and MacGregor Pelikánová, 2014b).

Over time, and after several CAP reforms, the focus has shifted from quantitative aspects to qualitative aspects, and a new balance between measures, such as direct payments, interventional mechanisms, quotas, exports and import licenses and structural means, was reached. The new CAP was envisioned by a Communication of the European Commission COM 2010(672) The CAP towards 2020: Meeting the food, natural resources and territorial challenges of the future ("CAP towards 2020) and took effect from 2014 with its two closely intra-bound pillars linked to structural funds. The information below on finances assignment for 2014-2020, further magnifies that.

Hence, under the auspices of Europe 2020, the new CAP is set predominantly by the TEU, TFEU and a handful of Regulations, and further developed by the Common strategic framework on the international level and by the Agreement on Partnership on the national level. The overview of key legislative instruments creating the backbone of the new CAP is provided in Table 1 and reveals that the new CAP belongs to the sphere of the conferred shared competence allowing the EU to act only towards the set objectives! 
Tab 1. Overview of the framework for the new CAP. Source: Prepared by authors

\begin{tabular}{|c|c|}
\hline $\begin{array}{l}\text { Instrument - Type, Name, } \\
\text { Comments }\end{array}$ & Title/Content/Provision/Comments \\
\hline Strategic - Europe 2020 & $\begin{array}{l}3 \text { priorities (smart, sustainable, inclusive growth) }-5 \text { targets } \\
-7 \text { flagship initiatives } \\
\text { "All EU policies, instruments and legal acts, as well as } \\
\text { financial instruments, should be mobilised to pursue } \\
\text { the strategy's objectives" }\end{array}$ \\
\hline $\begin{array}{l}\text { Primary EU law - TEU } \\
\text { ! Principle of subsidiarity - } \\
\text { only as the objectives } \\
\text { cannot be achieved by EU } \\
\text { member states! }\end{array}$ & $\begin{array}{l}\text { Art. } 3 \text { EU shall pursue its objectives by appropriate means } \\
\text { commensurate with the competences which are conferred } \\
\text { upon it in the Treaties } \\
\text { Art. } 5 \text { The limits of EU competences are governed by } \\
\text { the principle of conferral. The use of EU competences is } \\
\text { governed by the principles of subsidiarity and } \\
\text { proportionality... Under the principle of subsidiarity, in areas } \\
\text { which do not fall within its exclusive competence, the Union } \\
\text { shall act only if and in so far as the objectives of the } \\
\text { proposed action cannot be sufficiently achieved by the } \\
\text { Member States, either at a central level or at regional and } \\
\text { local levels, but can rather, by reason of the scale or effects } \\
\text { of the proposed action, be better achieved at the Union } \\
\text { level. }\end{array}$ \\
\hline Primary EU law - TFEU & $\begin{array}{l}\text { Art. } 4 \text { shared competence for agriculture and fisheries } \\
\text { Art. } 38 \text { et foll. agriculture and fisheries }\end{array}$ \\
\hline $\begin{array}{l}\text { Secondary EU law - } \\
\text { Regulation } 1305 / 2013\end{array}$ & $\begin{array}{l}\text { Support for rural development by the European Agricultural } \\
\text { Fund for Rural Development (EAFRD) }\end{array}$ \\
\hline $\begin{array}{l}\text { Secondary EU law - } \\
\text { Regulation } 1306 / 2013\end{array}$ & $\begin{array}{l}\text { Financing, management and monitoring of the common } \\
\text { agricultural policy }\end{array}$ \\
\hline $\begin{array}{l}\text { Secondary EU law - } \\
\text { Regulation } 1307 / 2013\end{array}$ & Rules for direct payments to farmers \\
\hline $\begin{array}{l}\text { Secondary EU law - } \\
\text { Regulation } 1308 / 2013\end{array}$ & Common organization of the markets in agricultural products \\
\hline $\begin{array}{l}\text { Secondary EU law - } \\
\text { Regulation 639/2014 }\end{array}$ & $\begin{array}{l}\text { Transfer of competencies regarding direct payments to } \\
\text { the European Commission, Conditions for "active farmers" } \\
\text { and "young farmers" (relation to Regulation 1307/2013) }\end{array}$ \\
\hline
\end{tabular}

The above indicated framework of the new CAP is to be materialized, namely its objectives are to be reached, through financial support provided by the EU budget via two funds, the European Agricultural Guarantee Fund (EAGF) for direct support and funds market measures and the European Agricultural Fund for Rural Development (EAFRD) finances rural development, and national budgets as well as other resources. Although during the 1980s, the CAP took annually $66 \%$ of the EU budget, the new CAP takes annually only $37.8 \%$. Still, the total amount spent from the EU budget on the new CAP during the years 2014-2020 reaches the impressive total of EUR 408 billion, of which the $1^{\text {st }}$ pillar takes EUR 308.726 billion $(75.6 \%)$ and the $2^{\text {nd }}$ pillar takes EUR 99.587 billion (24.4\%). Namely, in 2018, the EU supports farmers with EUR 59 billion of which EUR 42 billion goes towards income support, EUR 14 billion for rural development measures and EUR 3 billion for market measures (EC, 2018). 
Tab 2. Overview of the new CAP budget 2014-2020. Source: Prepared by authors based on the information provided by the European Parliament on

http://www.europarl.europa.eu/atyourservice/en/displayFtu.html?ftuld=FTU_5.2.2.html

\begin{tabular}{|l|r|}
\hline \multicolumn{1}{|c|}{ CAP Budget 2014-2020 } & Total 2014-2020 (EUR billion at current prices) \\
\hline MARKET MEASURES & 19.002 \\
- assigned revenue & $(4.704)$ \\
- crisis reserve & 3.155 \\
TOTAL = 4.3\% of CAP & 17.453 \\
\hline DIRECT PAYMENTS & 298.438 \\
- transfers to pillar 2 & $(7.369)$ \\
- transfers to direct payments & 3.359 \\
TOTAL = 71.3\% of CAP & 291.273 \\
\hline RURAL DEVELOPMENT & 95.577 \\
- net balance in favour of pillar 2 & 4.010 \\
TOTAL = 24.4\% & 99.587 \\
\hline
\end{tabular}

These EU frameworks and calculations are to be understood in the national contexts. For example, the Czech agricultural sector has undergone many changes over the last 30 years (Némethová \& Civáň, 2017). In particular, since the accession to the EU in 2004, there has been a rapid drop in particular breeds of animals, a transformation of their structure and way of breeding, the structure of the general food sector (Věžník et al., 2013) and increasing importance of the landscaping function of agriculture (Vaishar \& Zapletalová, 2009). These changes were heavily influenced by the provided financing, especially from the EU. Indeed, from 2004 to 2016, the Czech Republic paid EUR 473.3 billion to the EU budget, but got from the EU budget during the same period EUR 1100 billion. Hence, the positive balance for the Czech Republic for 20042016 was EUR 639 billion and came predominantly from structural and cohesion funds, followed by financing to support the development of agriculture and rural development. Regarding the new CAP, for the period from 2015 to 2020, the Czech Republic was assigned CZK 23 billion within the $1^{\text {st }}$ pillar, for direct payments calculated based on surface, and CZK 8 billion within the $2^{\text {nd }}$ pillar, for rural development. Naturally, these figures are to be appreciated while keeping in mind national support, i.e., financial and non-financial support for agriculture, both production and rural development, provided from the national public and other sources. These financial and other instruments have pushed for the increase of the exploited land by a farming person or entity and of the use of modern technologies. Allegedly, they have contributed to a decrease of farming subjects in the Czech Republic, i.e., the phenomenon of the "rural desertion" and a rural demographic drop (Vaishar et al., 2016), and to the market asymmetry and conflicts among big and small farmers in the Czech Republic, as well as in other EU member states (Sexton, 2012).

\section{Material and methods}

In order to scientifically and academically identify the objectives of the new CAP and assess their (mis)compliance, a multi-disciplinary research needs to be performed and the yielded information has to be holistically processed by Meta-Analysis (Silverman, 2013) while maintaining an openminded approach and adding a critical closing and commentary being refreshed by socratic questioning (Areeda, 1996). The involvement of economic, legal and other features and the embracing of both qualitative and quantitative data requires both deductive and inductive aspects of legal and scientific thinking (Matejka, 2013). Firstly, the objectives and their (mis)reconciliation in each of three spheres (legislative, academic, general public) will be found and discussed. Secondly, objectives from all three spheres will be mutually confronted.

Hence, firstly, the EU legislative backbone of the new CAP must be interpreted, both based on the literal method and on the teleological-purposive method (MacGregor Pelikánová, 2014a) in order to extract, present and intra-pose the expressed and explicit objectives. Similarly, academic treatises, especially those included in the WoS and Scopus databases, along with official and semi-official statements and opinions, are to be researched and mentioned or implied objectives 
of the new CAP are to be pinpointed, described and intra-posed. Ultimately, a like process is to be conducted vis-à-vis the general public perceptions and expectations regarding the objectives of the new CAP and their (mis)reconciliation. This part is very challenging and is to be done via a new Czech micro-case study, based on questionnaires and interviews, and prior case studies reported in academic literature. This new Czech micro-case study involves a set of close, semiopen and open questions targeting the awareness, use, criticism and assessment of the new CAP and its objectives by 10 respondents - Czech farmers and farm businesses fitting the criteria of SMEs and benefiting by, i.e., using, the new CAP financing via direct payments and RDP Leader. Since a statistical threshold of this homogenous group of respondents was not met, the yielded data is indicative. In addition, the quantitative insufficiency of the responding sample is at least partially offset by the consideration of similar case studies performed abroad, e.g., in Italy (Severini \& Sorrentino, 2017) as well as domestically, e.g., about small rural towns in South Moravia (Malý, 2016) or about the cooperation of municipalities in South Bohemia (Dušek, 2017), as well as abroad, e.g., in Poland about certain regions and their organic farming under the auspices of the new CAP (Śpiewak, 2016). Then, secondly, the identification and assessment of the potential for reconciliation of these objectives within each of these three spheres (legislative, academic and general public) is finally completed by the assessment and inter-position of these objectives across these three spheres. Hence, the presented data and arguments, along with the offered semi-conclusions, are not presented as robustly objective and dogmatically conclusive, but rather they are reflecting the used background, Central European particularities and the formed opinions of authors. Therefore, they contribute to the ongoing broad discussion.

In summary, the objectives of the new CAP are the leitmotif and the underlying hypotheses are that these objectives can be identified $(\mathrm{H} 1)$, are very heterogonous $(\mathrm{H} 2)$ and so even contraproductive $(\mathrm{H} 3)$. The confirmation of these three hypotheses, along with the involved arguments and discussion, should offer a potential for improvement, i.e., to make the objectives of the new CAP more compliant and mutually supporting and less contradictory unto themselves. Indeed, a smart, sustainable and inclusive growth, proclaimed by Europe 2020, demands a reconciliation of the new CAP's efforts and objectives and cannot afford their fragmentation and anti-polarity. 


\section{Results - overview of new CAP objectives in legislative, academic and laic perspectives}

The legislative perspective regarding objectives of the new CAP was preliminarily proposed by the CAP towards 2020, which indicates three strategic aims, i.e., objectives, see Table 3.

Tab 3. Overview of objectives proposed by the CAP towards 2020. Source: Prepared by authors based on the wording of the CAP towards 2020

\begin{tabular}{|c|c|}
\hline Aim & Explanatory comments \\
\hline $\begin{array}{l}\text { To preserve the food production } \\
\text { potential on a sustainable basis } \\
\text { throughout the EU, so as to } \\
\text { guarantee long-term food security } \\
\text { for European citizens and to } \\
\text { contribute to the growing world } \\
\text { food demand, expected by FAO } \\
\text { to increase by } 70 \% \text { by } 2050\end{array}$ & $\begin{array}{l}\text { Recent incidents of increased market instability, often } \\
\text { exacerbated by climate change, further highlight these } \\
\text { trends and pressures. Europe's capacity to deliver } \\
\text { food security is an important long term choice for } \\
\text { Europe which cannot be taken for granted. }\end{array}$ \\
\hline $\begin{array}{l}\text { To support farming communities } \\
\text { that provide the European citizens } \\
\text { with quality, value and diversity of } \\
\text { food produced sustainably, in line } \\
\text { with our environmental, water, } \\
\text { animal health and welfare, plant } \\
\text { health and public health } \\
\text { requirements. }\end{array}$ & $\begin{array}{l}\text { The active management of natural resources by } \\
\text { farming is one important tool to maintain the rural } \\
\text { landscape, to combat biodiversity loss and contributes } \\
\text { to mitigate, and to adapt to, climate change. This is an } \\
\text { essential basis for dynamic territories and long term } \\
\text { economic viability. }\end{array}$ \\
\hline $\begin{array}{l}\text { To maintain viable rural } \\
\text { communities, for whom farming is } \\
\text { an important economic activity } \\
\text { that creates local employment }\end{array}$ & $\begin{array}{l}\text { This delivers multiple economic, social, environmental } \\
\text { and territorial benefits. A significant reduction in local } \\
\text { production would also have implications with regards } \\
\text { to greenhouse gases (GHG), characteristic local } \\
\text { landscapes as well as more limited choices for } \\
\text { the consumer. }\end{array}$ \\
\hline
\end{tabular}

The legislative perspective regarding objectives of the new CAP is cemented by the backbones of the new CAP legislation. The literal interpretation calls to point out these legislative instruments and cite from them what they label as "objectives" of the new CAP. The teleological-purposive interpretation goes in more depth and departs from the strictly literal meaning. Table 4, below, provides an overview of objectives of the new CAP in the legislative perspective, while presenting it in two columns - one for literal and the other for teleological-purposive interpretation. 
Tab 4. Overview of objectives stated by new CAP legislative instruments. Source: Prepared by authors

\begin{tabular}{|c|c|c|}
\hline $\begin{array}{l}\text { Legislative } \\
\text { Instrument }\end{array}$ & Literal interpretation of objectives (quotation) & $\begin{array}{c}\text { Teleological-purposive } \\
\text { interpretation of objectives }\end{array}$ \\
\hline TFEU & $\begin{array}{l}\text { Art.39 } \\
\text { "(a) to increase agricultural productivity by } \\
\text { promoting technical progress and by ensuring } \\
\text { the rational development of agricultural } \\
\text { production and the optimum utilisation of } \\
\text { the factors of production, in particular labour; } \\
\text { (b) thus to ensure a fair standard of living for } \\
\text { the agricultural community, in particular by } \\
\text { increasing the individual earnings of persons } \\
\text { engaged in agriculture; } \\
\text { (c) to stabilise markets; } \\
\text { (d) to assure the availability of supplies; } \\
\text { (e) to ensure that supplies reach consumers } \\
\text { at reasonable prices." }\end{array}$ & $\begin{array}{l}\text { Across the TEU and TFEU, } \\
\text { the agriculture is discussed as } \\
\text { a part of the internal market. } \\
\text { Indeed, the TEU and TFEU } \\
\text { demonstrate a zealous } \\
\text { commitment to the internal } \\
\text { market, see their introductory } \\
\text { provisions. }\end{array}$ \\
\hline $\begin{array}{l}\text { Regulation } \\
1305 / 2013 \\
\text { Support for } \\
\text { Rural } \\
\text { development }\end{array}$ & $\begin{array}{l}\text { Art.4 } \\
\text { "(a) fostering the competitiveness of } \\
\text { agriculture; } \\
\text { (b) ensuring the sustainable management of } \\
\text { natural resources, and climate action; } \\
\text { (c) achieving a balanced territorial } \\
\text { development of rural economies and } \\
\text { communities, including the creation and } \\
\text { maintenance of employment." }\end{array}$ & $\begin{array}{l}\text { The Preamble ad 2) indicates } \\
\text { that RDP is established to } \\
\text { accompany and complement } \\
\text { direct payments and market } \\
\text { measures of the CAP. } \\
\text { The objectives from TFEU and } \\
\text { Europe } 2020 \text { are to be } \\
\text { observed, especially general } \\
\text { objectives for the economic and } \\
\text { social cohesion policy. }\end{array}$ \\
\hline $\begin{array}{l}\text { Regulation } \\
1306 / 2013 \\
\text { Financing } \\
\text { and } \\
\text { Monitoring }\end{array}$ & $\begin{array}{l}\text { Art.1 } \\
\text { "This Regulation lays down the rules on: } \\
\text { (a) the financing of expenditures under } \\
\text { the Common Agricultural Policy (CAP), } \\
\text { including expenditures on rural development; } \\
\text { (b) the farm advisory system; } \\
\text { (c) the management and control systems to } \\
\text { be put in place by the Member States; } \\
\text { (d) the cross-compliance system; } \\
\text { (e) clearance of accounts." } \\
\text { Art.3 } \\
\text { "In order to achieve the objectives of the CAP } \\
\text { as set out in the TFEU,..." }\end{array}$ & $\begin{array}{l}\text { Observing the CAP towards } \\
2020 \text {, see the Preamble } \\
\text { Economic objectives, see } \\
\text { the Preamble ad } 65 \text { ) } \\
\text { Viable food production and } \\
\text { climate, see the Preamble ad } \\
68 \text { ) } \\
\text { Protection of financial interests } \\
\text { of the EU, see the Preamble ad } \\
72 \text { ) } \\
\text { Reinforcing controls, see } \\
\text { the Preamble ad } 74 \text { ) } \\
\text { Reinforcing public controls, see } \\
\text { the Preamble ad } 80 \text { ), etc. }\end{array}$ \\
\hline $\begin{array}{l}\text { Regulation } \\
1307 / 2013 \\
\text { Direct } \\
\text { payments }\end{array}$ & $\begin{array}{l}\text { Art.1 to establish } \\
\text { „(a) common rules on payments granted } \\
\text { directly to farmers under the support } \\
\text { schemes listed in Annex I ("direct } \\
\text { payments"); } \\
\text { (b) specific rules concerning ..." }\end{array}$ & $\begin{array}{l}\text { Reduction of administrative } \\
\text { burden, see the Preamble ad } 2 . \\
\text { Observing the CAP towards } \\
2020 \text {, see the Preamble. For } \\
\text { drive for objective criteria, see } \\
\text { Art. } 9 \text { et foll., Art. } 30 \text { et foll. }\end{array}$ \\
\hline
\end{tabular}

The legislative objectives for the $2^{\text {nd }}$ pillar, i.e., for the RDP and national Agreements on Partnerships, set by the Regulation 1305/2013, are summarized in more detail by the Table 5 . Particularly, Table 5 focuses on the Czech Republic and assigned finances for these six priorities, i.e., objectives. 
Tab 5. Overview of RDP, priorities and financing in 2015-2020 for the Czech Republic. Source: Prepared by authors based on the information from the Czech Agrarian Chamber

\begin{tabular}{|c|c|c|}
\hline Priorities & Description & $\begin{array}{l}\text { Finances in mil. } \\
\text { EUR }\end{array}$ \\
\hline Priority 1 & $\begin{array}{l}\text { Fostering knowledge transfer and innovation in } \\
\text { agriculture, forestry, and rural areas. }\end{array}$ & 117 \\
\hline Priority 2 & $\begin{array}{l}\text { Enhancing farm viability and competitiveness of all types } \\
\text { of agriculture in all regions and promoting innovative farm } \\
\text { technologies and the sustainable management of forests } \\
\text { (competitiveness of the agricultural sector) }\end{array}$ & 571 \\
\hline Priority 3 & $\begin{array}{l}\text { Promoting food chain organisation, including processing } \\
\text { and marketing of agricultural products, animal welfare and } \\
\text { risk management in agriculture. }\end{array}$ & 152 \\
\hline Priority 4 & $\begin{array}{l}\text { Restoring, preserving and enhancing ecosystems related } \\
\text { to agriculture and forestry, including Natura } 2020 \text { (! The } \\
\text { most significant part, i.e., the expected allocation of } \\
\text { financial resources for environment protection reaches } \\
59.16 \% \text { of RDP!). }\end{array}$ & 1954 \\
\hline Priority 5 & $\begin{array}{l}\text { Promoting resource efficiency and supporting the shift } \\
\text { towards a low carbon and climate resilient economy in } \\
\text { agriculture, food and forestry sectors. }\end{array}$ & 23 \\
\hline Priority 6 & $\begin{array}{l}\text { Promoting social inclusion, poverty reduction and } \\
\text { economic development in rural areas. }\end{array}$ & 230 \\
\hline
\end{tabular}

The provided legislative overview demonstratively and obviously confirms all three hypotheses. Yes, the EU law states and implies objectives $(\mathrm{H} 1)$, which are very heterogonous $(\mathrm{H} 2)$ and the following examples included in Table 6 show their opposition and perhaps even their contraproductive nature $(\mathrm{H} 3)$. 
Tab 6. Overview of certain heterogenous objectives offered by the legislative perspective. Source: Prepared by authors

\begin{tabular}{|l|l|l|}
\hline \multicolumn{1}{|c|}{ EC } & \multicolumn{1}{|c|}{ TEU, TFEU } & \multicolumn{1}{c|}{$\begin{array}{c}\text { Regulations } \\
(1305 / 2013 \text { and 1307/2013) }\end{array}$} \\
\hline $\begin{array}{l}\text { To preserve the food } \\
\text { production }\end{array}$ & $\begin{array}{l}\text { To increase agricultural } \\
\text { productivity to stabilize } \\
\text { markets }\end{array}$ & $\begin{array}{l}\text { Fostering the competitiveness of } \\
\text { agriculture }\end{array}$ \\
\hline $\begin{array}{l}\text { To support farming } \\
\text { communities }\end{array}$ & $\begin{array}{l}\text { To ensure a fair standard } \\
\text { of living for the agricultural } \\
\text { community to ensure that } \\
\text { supplies reach consumers } \\
\text { at reasonable prices }\end{array}$ & $\begin{array}{l}\text { Reduction of administrative } \\
\text { burdens }\end{array}$ \\
$\begin{array}{l}\text { Diversity of food produced } \\
\text { sustainably, in line with } \\
\text { our environmental, water, } \\
\text { animal health and welfare, } \\
\text { plant health and public } \\
\text { health requirements }\end{array}$ & $\begin{array}{l}\text { Insuring the sustainable } \\
\text { management of natural } \\
\text { resources, and climate action } \\
\text { achieving a balanced territorial } \\
\text { development }\end{array}$ \\
\hline $\begin{array}{l}\text { Comments - examples of contradictions: } \\
\text { - Preserving the food production v. increasing productivity v. stabilizing market } \\
\text { (increase and stabilization are not easily reconcilable, preservation generally does not }\end{array}$ \\
$\begin{array}{l}\text { support productivity increases, etc.) } \\
\text { Supporting farming communities and fair } \\
\text { v. competitiveness (competition often leads to the drive for the maximization of profits } \\
\text { and disregards fairness, communities support, etc.) } \\
\text { Increasing productivity v. developing diversity of food produced, ... (diversity generally } \\
\text { decreases the productivity, etc.). } \\
\text { - Fostering competitiveness v. sustainable management of natural resources, climate.. } \\
\text { (competitiveness often promotes short-term gratification and leads to disrespect of } \\
\text { the long-term "expensive" goals, etc). }\end{array}$ \\
\hline
\end{tabular}

The academic perspective regarding objectives of the new CAP is founded upon the premise that the objectives of the new CAP are to be implied by the EU law and to contribute to smart, sustainable, and inclusive growth, to the single internal market and to R\&D leading to innovations on the national markets as well as the entire single internal market (MacGregor Pelikánová, 2017). Further, academic papers published and classified in the well-recognized databases, such as WoS and Scopus, point out that Europe 2020 attempts to address the post-crises issues, fiscal disparities (Balcerzak, 2016b and Růžičková \& MacGregor Pelikánová, 2014), structural diversity (Balcerzak, 2015), and generally the perception of the integration by all stakeholders (Piekarczyk, 2016) and the rather disappointing performance of the EU until 2010 linked, among other factors, to the underemployment of the technological potential (Balcerzak, 2016a and PohulakŻoledowska, 2016). This endeavor and its results are assessed based on the usual criteria of effectiveness and efficiency, often along with the ultimate liability of all stakeholders (Cvik \& MacGregor Pelikánová, 2016). Despite all these complexities, the new CAP should reduce the bureaucracy and administrative burden, see Regulation 1307/2013, simplify the entire system and make it more flexible and transparent (EC, 2018) and mitigate differences between EU member states and their agricultural performance (Reiff et al., 2016). The academic sphere immediately add that this objective is hardly materialized and moves on to discussing other issues. Regarding the $1^{\text {st }}$ pillar, the traditional principle of a fixed amount per surface, provided it is at least one hectare of agricultural land, remains and is complemented by other direct payments for active farmers and farm businesses, which satisfy a set criteria, e.g., being a young farmer. Arguably, such a $1^{\text {st }}$ pillar contributes to an increase in the employment in labor intensive fields of agriculture as well as to the increase of environmental pollution (Helming \& Tabeau, 2017). Regarding the $2^{\text {nd }}$ pillar, RDP, it is pointed out that it is closely linked to the $1^{\text {st }}$ pillar (direct 
payments) as well as to structural funds and should lead to agricultural processes which are both safer and climate and environmental friendly. For example, it is emphasized that Regulation $1305 / 2013$ should lead to the possibility of an enlarged crop insurance program in the EU (Fusco et al., 2018). These propositions need to be critically appreciated in the light and context of the above indicated heterogenous objectives (see Table 6).

The above described and below further developed academic perspective regarding both pillars indentifies a number of objectives of the CAP and implies their heterogeneity, i.e., aims to confirm both $\mathrm{H} 1$ and $\mathrm{H} 2$. Indeed, although objectives and effects of both pillars are perceived as at least partially conflicting, many academic authorities attempt to reconcile them, or at least to present them simultaneously while skipping or underestimating their potential conflict. Indeed, it cannot be overemphasized that the multitude and heterogeneity of objectives is a logical and typical result of preceding negotiation process carried by EU institutions and EU member states. Basically, this is a EU modus operandi leading sometimes to effective and efficient compromises and sometimes not. It is emphasized that the new CAP promotes the progressive dismantling of the price support system in favor of market-oriented production, i.e., decoupling, and rural development (Severini \& Sorrentino, 2017). Optimistically, it is proposed that the new CAP should promote competitiveness, the efficient use of public goods, food security, preservation of the environment and specific action against climate change, social and territorial equilibrium, and a more inclusive rural development (Nazzaro \& Marrota, 2016). However, this is not a unified tenor and the dissent should not be overlooked. Some authors remind us that the new CAP and its objectives need to vigorously work on the balance between commercial and non-commercial functions of the agricultural sector (Śpiewak, 2016) and support various types of sustainability, including economic, social and demographic sustainability of rural areas (Vaishar et al., 2016). The standing of farmers (and some EU farmers are out standing in their fields) in the agriculture and agricultural value chain is to be reinforced (Velázquez \& Buffaria, 2017; Cacchiarelli et al., 2018). Even stronger dissenting voices argue that the EU farming and agricultural sector remain as very important sectors to preserve and stimulate employment and economic growth in rural areas (Hill, 2012), i.e., the new CAP should keep jobs in a competitive and environmental and rural friendly agriculture (Helming \& Tabeau, 2017). However, the introduction of the Single Payment Scheme or system of decoupled payments to farmers in the $1^{\text {st }}$ pillar of the CAP leads to a decrease in employment in the agriculture sector (Petrick \& Zier, 2012) and further magnifies the differences in the optimized crop production in terms of resource savings and output maximization, between "old" and "new" EU member states (Toma et al., 2017). This is one of many paradoxes of the conceptual setting (effectiveness) and application (efficiency) of the new CAP and contributes to the suggestion that, after all, the new CAP could be more effective (Helming \& Tabeau, 2017). After having said that, it is obvious that academics do not hesitate to suggest that the objectives of the new CAP can become, or even directly are, contra-productive. This leads to the confirmation of $\mathrm{H} 3$ on the academic level.

It would be remiss to end the review of the legislative perspective by only confirming all three hypotheses and not pointing out one more very strong problem of the new CAP and its objectives, which was revealed by academia. Specifically, many academics discuss the information asymmetry and the low awareness about the new CAP objectives by the ultimate stakeholders and propose that states, regions, municipalities, farm businesses and even farmers themselves should work harder, either independently or better yet, in cooperation, so as to understand the new CAP and to be able to benefit by the appropriate financial resources (Dušek, 2017). This should be doable because basically the ideational framework has remained largely intact (Greer, 2017). Thus, for example, in the Czech Republic, there are critical voices regarding the direct and indirect impact of the new CAP, the (alleged) punishment of small farmers not wanting to go for production "at any price" driven and not having resources to study the entire new CAP maze. While the Czech Ministry of Agriculture presents generally positive opinions, typically while using the portal eAgri, academics are split (Věžník et al., 2016). Particularly, they point out a structural imbalance (Kř́stková \& Ratinger, 2014), farmer ageing (Zagata et al., 2015), decrease of the rural population (Vaishar et al., 2016), disadvantages for small farmers and asymmetry of information (Sexton, 2012), negative impacts on the countryside (Prášilová \& Procházková, 2016), the threat for the long-term competitiveness of Czech agriculture and food sovereignty, food self-sufficiency, and food security. Pursuant to the common tenor, the balance between natural resources of 
the given territory and consumption moved into the forefront of societal concern (Prášilová \& Procházková, 2016).

This is observed not only by academia but as well by the majority of the general public, which is all too aware that the biggest bulk of the financing of the new CAP still goes to the direct payments of the $1^{\text {st }}$ pillar, which are paid based on the surface and the $2^{\text {nd }}$ pillar just slowly with its six priorities mitigate what is caused by the negative impact of the $1^{\text {st }}$ pillar. This is obvious in the Czech Republic, where a large part of the agricultural production is provided by large farm businesses, where the general productivity is still behind the EU average and where agricultural production has a strongly negative impact on the environment, such as exhaustion and pollution of the land or the devastation of water resources. These rather strong statements are implied by the field search and confirmed by micro-sample interviews involving semi-open questions. All 10 respondents were Czech farmers and farm businesses fitting the criteria of SMEs and benefiting, i.e., by using the new CAP financing via direct payments and RDP Leader. Hence, they constitute a homogenous micro-sample not meeting criteria for statistical assessment, but still relevant enough to provide indices and suggestions. The involved questions and provided feedback are presented in Table 7, below, and show that the general public is able to point out the objectives of the new CAP, critically comment on their heterogeneity and their failed or contraproductive application, and to observe that the agricultural performance disparity between EU member states is not decreasing, i.e., the intensive agriculture of Benelux, France, Germany and Denmark surpassed all the rest (Reiff et al., 2016). The general public statements confirm all three hypotheses, along with expressing their frustration with the current EU political situation and the Czech political situation (criticism of the prime minister who is the (ex) owner of the biggest Czech agriculture holding).

The yielded data along with the above presented legislative, academic and literature overview, and especially the Czech micro-case study, allows us to proceed to the presentation of results and to a dynamic discussion. 
Tab 7. New CAP objectives - suggestions and feedback by Czech SME farmers. Source: Prepared by authors based on their questionnaire investigation and interviews

\begin{tabular}{|c|c|}
\hline Objective & Replies and Feedback \\
\hline $\begin{array}{l}\text { Fairness of } \\
\text { the new CAP } \\
\text { system (fair } \\
\text { for all EU } \\
\text { member } \\
\text { states) }\end{array}$ & $\begin{array}{l}\text { "The EU works "on three speeds", i.e., the EU member states are split into } \\
\text { three groups - the old } 12 \text { EU member states having a preferential new CAP } \\
\text { treatment, "states of the } 2^{\text {nd }} \text { category", such as the Czech Republic, having } \\
\text { a less beneficial treatment and "states of the } 3^{\text {rd }} \text { category", such as Bulgaria } \\
\text { and Romania, having the worst treatment." } \\
\text { "This problem is magnified by the diversity of national coefficients for direct } \\
\text { payment paid, based on the surface, so farmers from wealthy states not } \\
\text { only enjoy the new CAP preferential treatment, but as well a higher national } \\
\text { support, and this totally deforms the single internal agricultural market, as } \\
\text { is very visible vis-à-vis sensitive agricultural products." } \\
\text { The system unfairness should be mitigated by modernizing the new CAP } \\
\text { and having exactly the same conditions for each and every EU member } \\
\text { state." } \\
\text { "We are fed-up, how can we compete against big farming businesses from } \\
\text { other EU member states that are providing huge national subsidies!" }\end{array}$ \\
\hline $\begin{array}{l}\text { No } \\
\text { discrimination } \\
\text { between } \\
\text { farmers }\end{array}$ & $\begin{array}{l}\text { "There is a big discrimination between small and big farmers caused by } \\
\text { the mechanism of direct payments of the new CAP." } \\
\text { "There should be a cap for a maximum calculated surface." } \\
\text { "There should be a maximum direct payment paid to one subject." } \\
\text { "The financial support for agriculture under the auspices of the CAP is } \\
\text { neither correctly set nor correctly applied, because the entire system } \\
\text { appears to be set and works better for certain subjects than others. }\end{array}$ \\
\hline $\begin{array}{l}\text { Reduced } \\
\text { administrative } \\
\text { burden }\end{array}$ & $\begin{array}{l}\text { "The new CAP is very complicated and full of red tape and even } \\
\text { the Payment Agency sometimes does not know how to proceed". } \\
\text { "The new CAP is so bureaucratic and administratively demanding that we } \\
\text { need to use external experts to advise us, and this is an additional } \\
\text { expense." } \\
\text { "The new CAP is very complicated and we overcome this complexity by } \\
\text { actively searching for information from other new CAP recipients and from } \\
\text { the competent state administration and public authorities." } \\
\text { The modernized CAP is a bureaucratic maze with red tape. National } \\
\text { payment agencies and ministries contribute to this by adding further pitfalls } \\
\text { and traps." }\end{array}$ \\
\hline $\begin{array}{l}\text { Supporting } \\
\text { farming } \\
\text { communities }\end{array}$ & $\begin{array}{l}\text { "There is no positive motivation, i.e. there are only sanctions." } \\
\text { "The new CAP does not support farming communities, it supports } \\
\text { the biggest farming business which destroys farming communities } \\
\text { consisting of small and medium sized farmers and farm businesses." }\end{array}$ \\
\hline $\begin{array}{l}\text { Maintaining } \\
\text { viable rural } \\
\text { setting }\end{array}$ & $\begin{array}{l}\text { "There is a paradox of the current agricultural financing in the EU, } \\
\text { because the CAP has been financing intensive agricultural production } \\
\text { activities with bad, if not catastrophic, consequences for the rural } \\
\text { environment." } \\
\text { "The short term benefit of the intense production damages the entire } \\
\text { environment in the long term." } \\
\text { "Long-term sustainability is destroyed by the greed and abuse of BIG } \\
\text { farming businesses and top politicians." }\end{array}$ \\
\hline
\end{tabular}




\section{Discussion - (mis)compliance of the CAP objectives}

Objectives of the new CAP can be, and are identified by legislative documents, academic treatises and the general public. Particularly, legislative, academic and general public perspectives deal with objectives of the new CAP in an explicit manner. Therefore, the challenge of $\mathrm{H} 1$ cannot prevail and it needs to be unanimously confirmed that the new CAP objectives are known or at least believed to be known by basically all stakeholders. Indeed, the above presented theoretical background (Part 2) and results (Part 4) extract and propose many objectives. Interestingly, these objectives are not the same within each perspective and even not across these perspectives. Boldly, the search for the smallest common denominator is challenging, perhaps impossible. The objectives stated by Art.39 TFEU are already five in number, and the same language and expressions can be found only in some of the implementation Directives, but not e.g. in Europe 2020, which at least teleologically offers other objectives than those literally understood from the TFEU. The list of indentified objectives is further expanded by the general public and even by academia, which has generated an impressive amount of articles, including those classified in the WoS and/or Scopus, proposing and discussing these objectives, see below. This leads to the $\mathrm{H} 2$ about the nature of these objectives - are these objectives identical, unified or at least similar?

The identified objectives of the new CAP are definitely neither homogenous nor unified. Legislative documents, academic treatises and the general public produce an impressive abundance of (alleged) objectives of the new CAP. Therefore, the challenge of $\mathrm{H} 2$ cannot prevail and the fact that the new CAP objectives are numerous and often very different needs to be confirmed. Indeed, even within each of the discussed perspectives, there are several objectives of different natures. The five objectives stated by Art.39 TFEU seem to address the effectiveness in many angles, i.e., going for a number of "right things to be done". This plethora includes public macro-economic concerns (competition, market stability), private micro-economic concerns (productivity, price fairness) and social concerns (fair standard of living), i.e., it targets farmers and consumers as well as the market as such. The teleological interpretation of TFEU and the new CAP Regulations adds much further diversity and sometimes looks in its entire context absurd, see e.g., the proclaimed objective about the reduction of bureaucracy and administrative burden (Regulation 1307/2013) and the general simplification (EC, 2018). The legislative consolidation of these objectives is not provided on the strategic level, because Europe 2020 (allegedly) aims at the support of the competitiveness of agriculture, sustainable management of rural resources, and the economic development of rural areas (Némethová et al., 2014). Moving to the academic perspective, the abundance and fragmentation of objectives keeps increasing. Some authors observe the close link between the new CAP and the integration under the Europe 2020 and so name it as the top objectives the contribution to smart, sustainable, and inclusive growth, to the single internal market and to $R \& D$, leading to innovations on the national markets, as well as the entire single internal market (MacGregor Pelikánová, 2017). Other authors observe this trend but perceive as higher priorities of special sub-issues from the technological sphere (Balcerzak, 2016a and Pohulak-Żoledowska, 2016), fiscal sphere (Balcerzak, 2016b and Růžičková \& MacGregor Pelikánová, 2014), market structure sphere (Balcerzak, 2015; Severini \& Sorrentino, 2017) and environment sphere (Nazzaro \& Marrota, 2016; Śpiewak, 2016; Helming \& Tabeau, 2017). However, there are authors identifying objectives rather in relation to stakeholders than to market and integration (Piekarczyk, 2016). Finally, some authors observe that the stated objectives, such as the reduction of disparity, are not observed (Reiff et al., 2016). Similarly, the general public does not speak with one voice and entails various groups with different expectations and logically each of them perceives (subjectively) its "own" new CAP objectives. These groups entail, e.g., consumers, big farmers and small farmers, which - at least within the micro-case study format - show some frustration and questionability of discussed objectives of the new CAP. This leads to the $\mathrm{H} 3$ about the nature of these differences - are the new and different CAP objectives reconcilable or antagonistic?

The identified objectives of the new CAP are very dissonant. Legislative documents, academic treatises and the general public produce an impressive abundance of (alleged) objectives of the new CAP which allegedly resolve problems from almost all imaginable spheres. Quae Caesaris Caesari, quae Dei Deo (Mk 12,17) - Render that which is Caesar's to Caesar, and that 
which is God's to God, because already common sense teaches us that it is very difficult, but not impossible, to serve all. Indeed, the feasibility of such challenging reconciliation depends heavily upon the careful selection and involvement of independent instruments addressing such objectives (Tinbergen, 1956). In particular, the study of modern European integration is a perfect case-study material, consistently showing that it is impossible to impose from above (Brussels) a legislative solution creating win-win situations and settings for all Europeans (MacGregor Pelikánová, 2014a). Therefore, the challenge of H3 can hardly prevail and it needs to be rather suggested to confirm that the numerous new CAP objectives can, and sometimes even are, contra-productive and so the entire system is at risk of inefficiency. The legislative clashes are manifest from the above presented tables and the academic clashes are obvious from the presented papers. At the European level, this is pointed out e.g., by the vain attempt to reconcile the objectives of the agricultural diversification with the high-quality productivity, the rural development and the increase in the living standards of farmers (Śpiewak, 2016). It is even suggested that certain clearly established objectives, such as the mitigation of differences between EU member states in their agricultural performances, not only conflict with other objectives, but in addition fail to be materialized, i.e., the gap between old EU member states and new EU member states is growing (Reiff et al., 2016). Similarly, despite the stated objectives, there are still many obstacles for insurance schemes envisaged by the RDP (Bielza et al., 2009; Fusco et al., 2018). Where Italy enters into the conversation, it is presented along with a discourse about the contra-productive and inefficient coordination (Severini \& Sorrentino, 2017) and about the underestimation of negative externalities, such as adverse climatic event (Fusco et al., 2018). At the Polish level, it is presented along with organic and bio production issues (Śpiewak, 2016) and can be related to the highly interesting discussion about the concept of public goods (Czyżewski et al., 2016). Indeed, many academics express their deep concern that the current confusion and lack of a drive with respect to the new CAP objectives can have serious negative consequences in the future, such as conflicts among stakeholders (Sexton, 2012; Velázquez \& Buffaria, 2017), environment impacts (Fusco et al., 2018) or a decrease in the productivity and profitability in the agriculture sector (Madau et al., 2017). Some academics emphasize that the new CAP contributes to the heterogeneity of EU member states efficiency performances (Toma et al., 2017) and this contrasts with the Europe 2020 drive for sustainability and inclusion, and the general aim of the reduction of performance disparity (Reiff et al., 2016). The general public add its complaints about the injustice, especially linked to the direct payments plus additional "national" payments putting big farmers from certain "old EU member states" in a much better position than are small farmers from certain "new EU member states." Further, it can be detected by some authors (Śpiewak, 2016) or within the micro-case study of the general public, that, although modern farming is multifunctional and addresses economic, environmental, cultural, social and other needs, a clear and unified vision and key mission are needed. The starting point should be to make sure that the $1^{\text {st }}$ pillar and the $2^{\text {nd }}$ pillar of the new CAP do not contradict each other and that a sufficient awareness in this respect is reached (Dušek, 2017).

\section{Conclusions}

The new CAP is set and realized under the auspices of Europe 2020, which is built upon three priorities - smart, sustainable and inclusive growth. Both pillars of the new CAP, direct payments and support for the RDP, benefit by EU financial support via EAGF and EAFRD and absorb more than one third of the EU budget. The previous protectionist and production objectives were surpassed and replaced by new objectives. The legislative framework, with its backbone consisting of the TFEU and new CAP Regulations, as well as academia do not hesitate to name these objectives. These objectives are easily defined by a mere reading via the literal approach and by a purpose oriented study via the teleological approach. In addition, the general public is not shy to cite them also. There are no lingering doubts that the new CAP brought objectives which are neither hidden nor unknown. The current issue is not that we do know about new CAP objectives, but rather that we know about too many new CAP objectives. Hence, the $\mathrm{H} 1$ about the possibility to identify the new CAP objectives is confirmed beyond any doubt.

The study of new CAP objectives as identified from legislative documents, academic treatises and general public statements appears to be a very colorful Byzantine mosaic with modern 
abstract art features. Basically, many plausible concerns are put together without observing any leitmotif and without having a common smallest denominator. The new CAP objectives go from the productivity to diversity, from concerns for the market over concerns for farmers to concerns for consumers, from competitiveness to stability, from the EU concerns to very national concerns, from protection to discrimination. Indeed, each pillar of the new CAP leads to a set of various objectives and sadly it can hardly be denied that some of them are not fully transposed to practical life, see e.g., the underestimation of the $2^{\text {nd }}$ pillar and the lack of a pragmatic realistic approach to the drought, resulting in the lack of any proper insurance in Italy (Fusco et al., 2018). Indeed, there are many objectives and only some of them are fully observed and materialized. This can potentially impair the effectiveness of the entire new CAP system. In any case, H2 about the myriad of objectives is on its way towards confirmation.

This leads to the true burning question - can many of these objectives be both materialized and reconciled, or are they so antagonistic that it decreases the efficiency of the new CAP system? Well, the presented results, along with the discussion, point to many problems and obstacles. They do not conclusively prove that the new CAP objectives are unsuitable for reconciliation. Although, some of them look prima facia as contra-productive, they fail to be met (Reiff et al., 2016; Fusco et al., 2018) and cripple the efficiency, still, it cannot be denied that the prevailing tenor from abroad is rather positive and includes just a soft criticism regarding the setting and application of the new CAP objectives (Śpiewak, 2016; Madau et al., 2017; Severini \& Sorrentino, 2017; Fusco et al., 2018). Perhaps a somewhat harsher voice, but still rather positive, comes from the Czech Republic (Střeleček et al. 2004; Kabrda \& Jančák, 2006; Věžník \& Konečný, 2011; Svobodová, 2011; Král et al., 2012). Interestingly, the frustrations expressed in the micro-case study concerning the Czech SMEs did not bring forth any brand-new unknown issues. Since the presented data and arguments, along with the offered semi-conclusions, are influenced by the background information, orientation on Central Europe and via conducted analyses forming the opinions of the authors, they are not objectively conclusive, but rather they are rather presenting one opinion stream contributing to the ongoing broad discussion about the CAP and its objectives. Further, it cannot be overemphasized that the multitude and heterogeneity of objectives is not bad per se, instead it is a logical and typical result of prior negotiation process carried by EU institutions and EU member states and hence reflects the EU modus operandi. Hence, arguably, the fragmentation of the new CAP objectives does not impair or only partially impairs the effectiveness and efficiency of the new CAP, but definitely hurts the information and expectation level of the ultimate stakeholders.

Since the new CAP wants undoubtedly to achieve many, perhaps too many, good objectives and receive significant financial and other resources for that, it is deplorable that a lack of synchronization and communication of these objectives renders the new CAP ineffective and inefficient in certain perspectives. Hence, future research should not only target the multiobjectivity of the new CAP and the possible reconciliation of these objectives, but as well as the possibility of the enhancement of awareness and understandable transparency and fairness of the new CAP.

\section{Academic references}

[1] Areeda, Ph.E. (1996). The Socratic Method. Harvard Law Review, 109(5): 911-922.

[2] Balcerzak, A. P. (2016a). Technological Potential of European Economy. Proposition of Measurement with Application of Multiple Criteria Decision Analysis. Montenegrin Journal of Economics 12(3), 7-17. DOI: 10.14254/1800-5845.2016/12-3/1.

[3] Balcerzak, A. P. (2016b). Fiscal Burden in the European Union Member States. Economic Annals - XXI, 161(9-10), 4-6. DOI: 10.21003/ea.V161-01.

[4] Balcerzak, A. P. (2015). Europe 2020 Strategy and Structural Diversity Between Old and New Member States. Application of Zero Unitarization Method for Dynamic Analysis in the Years 2004-2013. Economics \& Sociology, 8(2): 190-210. DOI: 10.14254/2071789X.2015/8-2/14. 
[5] Bielza, Díaz-Caneja, M., Conte, C., Dittmann, C., Gallego Pinilla, F., Stroblmair, J. \& Catenaro, R. (2009). Risk Management and Agricultural Insurance Schemes in Europe. [JRC Reference Reports]. Luxembourg: Publication Office of EU. DOI: 10.2788/24307.

[6] Blacksell, M. (2010). Agriculture and landscape in $21^{\text {st }}$ century Europe: The post-communist transition. European Countryside, 2(1): 13-24. DOI: 10.2478/v10091-010-0002-8.

[7] Bočková, N. (2015). R\&D tax incentives in Czech enterprise. Scientific Papers of the University of Pardubice, Series D 21(1), 5-16.

[8] Cacchiarelli, L., Russo, C. \& Sorrentino, A. (2018). Market power and bargaining power in the EU food supply chain. NewMedit 17(4). DOI: $10.30682 / \mathrm{nm} 1804 \mathrm{~b}$.

[9] Cvik, E. D. \& MacGregor Pelikánová, R. (2016). A comparative study of the legal liability of executives in LLC in the Czech Republic \& some of other EU member states. Scientific Papers of the University of Pardubice, Series D 23(1), 54-65.

[10] Czyżewski, B., Polcyn, J. \& Hnatyszyn-Dzikowska, A. (2016). Concept for Measuring the Efficiency of Public Goods Provision Based on the Education Sector in Poland. Ekonomický časopis, 64(10): 973-993.

[11] Dušek, J. (2017). Evaluation of development of cooperation in South Bohemian municipalities in the years 2007-2014. European Countryside 9(2), 342-358. DOI: $10.1515 /$ euco-2017-0021.

[12] Fusco, G., Miglietta, P. P. \& Porrini, D. (2018). How Drought Affects Agricultural Insurance Policies: The Case of Italy. Journal of Sustainable Development, 11(2), 1-13. DOI: $10.5539 /$ jsd.v11n2p1.

[13] Greer, A. (2017). Post-exceptional politics in agriculture: an examination of the 2013 CAP reform. Journal of European Public Policy 24(11), 1585-1603. DOI: 10.1080/13501763.2017.1334080.

[14] Helming, J. \& Tabeau, A. (2017). The economic, environmental and agricultural land use effects in the European Union of agricultural labour subsidies under the Common Agricultural Policy. Regional Environmental Change 18(3), 763-773. DOI: 10.1007/s10113-016-1095-z.

[15] Hill, B. (2012). Farm incomes, wealth and agricultural policy - filing the CAP's core information gap, $4^{\text {th }}$ ed. Wallingford: CAB International.

[16] Kabrda, J. \& Jančák, V. (2006). České zemědělství a krajina po vstupu Česka do EU: nový instiutucionální rámec. In Kraft, S., Mičková, K., Rypl, J., Švec, P. \& Vančura, M., eds., Česká geografie v evropském prostoru (pp. 104-112). České Budějovice: Jihočeská univerzita.

[17] Král, M., Palasová, P., Svobodová, H. \& Věžník, A. (2012). Dopady SZP na rozvoj zemědělství v centrální části Drahanské vrchoviny. Geographia Cassoviensis, 6(2), 78-90.

[18] Křístková, Z. \& Ratinger, T. (2014). Potencionální distribuční efekty reformy Společné zemědělské politiky a vyvolaná strukturální změna. Ekononický časopis 62(5): 473-494.

[19] MacGregor Pelikánová, R. (2017). European Myriad of Approaches to Parasitic Commercial Practices. Oeconomia Copernicana 8(2), 167-180. DOI: 10.24136/oc.v8i2.11.

[20] MacGregor Pelikánová, R. (2014a). Selected current aspects and issues of European integration. Ostrava: Key Publishing.

[21] MacGregor Pelikánová, R. (2014b). The (DIS)harmony of opinions regarding domain names in the Czech Republic. Scientific Papers of the University of Pardubice, Series D21(1), 7384.

[22] MacGregor Pelikánová, R. (2013). Internet my dearest, what type of European integration is the clearest. Acta Universitatis Agriculturae et Silviculturae Mendelianae Brunensis 61(7), 2475-2481. DOI: 10.11118/actaun201361072475. 
[23] MacGregor Pelikánová, R, Císařová, J. \& Beneš, M. (2017). The misleading perception of the purpose of the protection against misleading advertising by the EU law and its impact on the Czech Republic. Lawyer Quarterly 7(3), 145-161.

[24] Madau, F. A., Furesi, R. \& Pulina, P. (2017). Technical efficiency and total factor productivity changes in European dairy farm sectors. Agricultural Food Economics 5, 17. DOI: 10.1186/s40100-017-0085-x.

[25] Malý, J. (2016). Small towns in the context of "borrowed size" and "agglomeration shadow" debates: The case of the South Moravian Region (Czech Republic). European Countryside 8(4), 333-350. DOI: 10.1515/euco-2016-0024.

[26] Matejka, J. (2013). Internet jako objekt práva - Hledání rovnováhy autonomie a soukromí. Praha: CZ.NIC.

[27] Martinát, S. \& Turečková, K. (2016). Local development in the post-mining countryside? Impacts of an agricultural ad plant on rural community. Geographia Technica 11(1), 54-66. DOI: 10.21163/GT_2016.111.07.

[28] Melecký, L. \& Staníčková, M. (2017). Cost Efficiency of EU Funded Projects: Case of Selected SMEs in the Moravian-Silesian Region. In: Strategic Management and its Support by Information Systems (pp. 293-302). Ostrava: VŠB TU Ostrava.

[29] Nazzaro, C. \& Marrota, G. (2016). The Common Agricultural Policy 2014-2020: scenarios for the European agricultural and rural systems. Agricultural and Food Economics, 4, 16. DOI: 10.1186/s40100-016-0060-y.

[30] Némethová, J. \& Civáň, M. (2017). Regional differences in agriculture in Slovakia after its accession to the European Union. Quaestiones Geographicae 36(2), 9-21. DOI: 10.1515/quageo-2017-0011.

[31] Némethová, J. Dubcová, A., Kramáreková, H. (2014). The impact of the European Union's Common Agricultural Policy in Slovakia. Moravian Geographical Reports 22(4), 51-64. DOI: $10.1515 / \mathrm{mgr}-2014-0023$.

[32] Pakšiová, R. (2016). Understanding of corporate social responsibility in large companies in Slovakia within the context of a sustainable development. In: Economic policy in the European union member countries: proceedings of $14^{\text {th }}$ international scientific conference (pp. 516-525). Opava: Silesian University.

[33] Petrick, M. \& Zier, P. (2012). Common Agricultural Policy effects on dynamic labour use in agriculture. Food Policy, 37, 671-678. DOI: 10.1016/j.foodpol.2012.07.004.

[34] Piekarczyk, A. (2016). Contemporary organization and a perspective on integration and development. Oeconomia Copernicana 7(3): 467-483. DOI: 10.12775/OeC.2016.027.

[35] Pohulak-Żoledowska, E. (2016). Innovation in Contemporary Economies. Oeconomia Copernicana 7(3), 451-466. DOI: 10.12775/OeC.2016.026.

[36] Prášilová, M. \& Procházková, R. (2016). Structural Changes of Czech Agriculture and the Impact of these on Inner Foodstuffs Self-Sufficiency of Czech Republic. In: Soliman, K. S., ed., Vision 2020: Innovation Management, Development Sustainability, and Competitive Economic Growth (pp. 2905-2919). Upper Merion, PA: IBIMA Publishing.

[37] Reiff, M., Surmanová, K., Balcerzak, A. \& Pietrzak, M. (2016). Multiple Criteria Analysis of European Union Agriculture Performance. Journal of International Studies 9(3), 62-74. DOI: 10.14254/2071-8330.2016/9-3/5.

[38] Růžičková, E. D. \& MacGregor Pelikánová, R. (2014). Recent trends in the regime of transfer tax in the Czech Republic and selected EU member states. Scientific Papers of the University of Pardubice, Series D 21(2), 25-33.

[39] Severini, S. \& Sorrentino, A. (2017). Efficiency and coordination in the EU agri-food systems. Agricultural and Food Economics, 5(1). 15. DOI: 10.1186/s40100-017-0086-9. 
[40] Sexton, R. J. (2012). Market power, misconceptions, and modern agricultural markets. American Journal Agricultural Economics 95(2), 209-219. DOI: 10.1093/ajae/aas102.

[41] Silverman, D. (2013). Doing Qualitative Research - A Practical Handbook. $4^{\text {th }}$ Edition, London: SAGE.

[42] Střeleček, F., Losová, J. \& Kvapilík, J. (2004). Development of livestock in numbers and structure from the regional and administrative aspects. Agricultural Economics - Czech, 50(2): 47-57.

[43] Svobodová, H. (2011). Vývoj zemědělské výroby v České republice pod vlivvem společné zemědělské politiky EU. Acta Regionalia et Environmentalica 8(1), 15-21.

[44] Śpiewak, R. (2016). Multifunctionality of organic farming: Case study from southern Poland. European Countryside 8(1), 1-15. DOI: 10.1515/euco-2016-0001.

[45] Tinbergen, J. (1956). Economic Policy: Principles and Design. Amsterdam: North Holland Publishing Company.

[46] Toma, P., Miglietta, P. P., Zurlini, G., Valente, D. \& Petrosillo, I. (2017). A non-parametric bootstrap-data envelopment analysis approach for environmental policy planning and management of agricultural efficiency in EU countries. Ecological Indicators 83, 132-143. DOI: 10.1016/j.ecolind.2017.07.049.

[47] Vaishar, A., Zapletalová, J., Nováková, E. (2016). Between urban and rural: Sustainability of small towns in the Czech Republic. European Countryside 8(4), 351-372. DOI: 10.1515/euco-2016-0025.

[48] Vaishar, A. \& Zapletalová, J. (2009). Sustainable development of rural microregions in the Czech borderland. Moravian Geographical Reports, 17(4): 34-43.

[49] Velázquez, G. \& Buffaria, B. (2017). About farmers' bargaining power within the new CAP. Agricultural and Food Economics 5, 16. DOI: 10.1186/s40100-017-0084-y.

[50] Věžník, A., Navrátil, M. \& Skácel, P. (2016). Czech Agriculture after Accession to EU: Changes, Regional Differences. In: Lněnička, L., ed., Procceding of $23^{\text {rd }}$ Central European Conference: Central Europe Area in View of Current Geography (pp. 373-380). Brno: Masaryk University. DOI: 10.5817/CZ.MUNI.P210-8314-2016.

[51] Věžník, A., Král, M. \& Svobodová, H. (2013). Agriculture of the Czech Republic in the $21^{\text {st }}$ century: From productivism to post-productivism. Quaestiones Geographicae 32(4), 7-14. DOI: 10.2478/quageo-2013-0029.

[52] Věžník, A. \& Konečný, O. (2011). Agriculture of the Czech Republic after accession to the EU: regional differentiation. Moravian Geographical Reports 19(1), 50-60.

[53] Zagata, L., Hádková, Š. \& Mikovcová, M. (2015). Basic outline of the problem of the "ageing population of farmers" in the Czech Republic. Agris On-line Papers in Economics and Informatics 7(1), 89-96.

\section{Other sources}

[54] European Commission (2018). Common Agriculture Policy at glance. Accessed on $7^{\text {th }}$ September 2018 and available at https://ec.europa.eu/info/food-farming-fisheries/keypolicies/common-agricultural-policy/cap-glance_en\#title.

[55] European Commission (2010). COM 2010(672) The CAP towards 2020: Meeting the food, natural resources and territorial challenges of the future. Accessed on $7^{\text {th }}$ September 2018 and available at EC ... https://ec.europa.eu/agriculture/sites/agriculture/files/cap-post2013/communication/com2010-672_en.pdf. 